\title{
Modelling Opportunities to Learn, Mathematical Belief and Knowledge for Teaching among Pre-service Teachers
}

\author{
Muhamad Nazri Abdul Rahman ${ }^{1 *}$, Sharifah Norul Akmar Syed Zamri ${ }^{1}$, Kwan Eu Leong ${ }^{1}$ \\ ${ }^{1}$ University of Malaya Faculty of Education, Kuala Lumpur, MALAYSIA
}

Received 4 April 2018 • Revised 19 December 2018 • Accepted 31 January 2019

\begin{abstract}
Issues about low level of mathematical knowledge for teaching among pre-service teachers has raised the question on the effectiveness of the mathematics teacher education program which has been planned and implemented by the Malaysian Institute of Teacher Education (MITE). This study was conducted to identify factors that affect mathematical knowledge for teaching (MKT) among pre-service teachers in Institute of Teacher Education (ITE). The influence of mathematical belief and opportunity to learn (OTL) have been tested to explain the factors affecting MKT. Using a structured questionnaire together with paper and pencil test adapted from the literature reviewed, data were collected from 105 pre-service teachers in MITE. Data were analysed using SmartPLS version 3.0. The result of the structural equation model indicated that OTL-Practicum $(\beta=0.491, p<0.001)$ and OTL-Program $(\beta=0.368, p<0.001)$ has a positive relationship with mathematical knowledge for teaching. Besides that, the result for the impact of OTL on mathematical belief, it showed that OTL-Practicum $(\beta=0.208, p<0.001)$ and OTL-Program $(\beta=0.243, p<0.001)$ has a positive relationship with constructivist belief, whereas OTL-Program was negatively related to traditional belief $(\beta=-0.283, p<0.001)$. Overall, the model explained $53.9 \%$ of the variance in mathematical knowledge for teaching. Implications from these findings to the ITE were further elaborated.
\end{abstract}

Keywords: opportunities to learn, mathematical belief, mathematical knowledge for teaching, constructivist belief, traditional belief

\section{INTRODUCTION}

The National Council of Teachers of Mathematics (NCTM) (2000) states that one of the principles of mathematics education is to enhance mathematical knowledge for teaching to become an effective teacher. Issues related to the knowledge of mathematics teachers and their role in classroom practice have been a major issue in mathematics education from the past (Wasserman, 2018). In addition, according to Fitzallen (2015) the mastery of mathematical content knowledge also contributes to the success in the implementation of four disciplines namely Science, Technology, Engineering and Mathematics (STEM).

The framework of mathematics teacher knowledge can be divided into two parts, the content knowledge and content knowledge for teaching mathematics framework (Holmes, 2012). According to Holmes (2012), the content knowledge framework consists of Bloom's Taxonomy (Bloom, Englehard, Furst, Hill, \& Krathwohl, 1956), Instrumental and Relational Understandings (Skemp, 1978); Procedural and Conceptual Understandings (Hiebert \& Carpenter, 1992) and Cognitive Complexities (Porter, 2002). Content knowledge for teaching frameworks include Shulman's (1986), Type of Teachers Knowledge and Ball's (2000) Mathematical Knowledge for Teaching Framework.

The concept of pedagogical content knowledge (PCK) was introduced by Shulman (1986) as so-called "a missing paradigm" in the study of teaching and teacher education. Shulman has criticized the lack of attention given to the content of lessons related to teaching and evaluation of pre-service teachers as well as studies on the effectiveness

(C) 2019 by the authors; licensee Modestum Ltd., UK. This article is an open access article distributed under the terms and conditions of the Creative Commons Attribution License (http://creativecommons.org/licenses/by/4.0/). \nazri1979@gmail.com (*Correspondence) \snorul@um.edu.my $\$ rkleong@um.edu.my 


\section{Contribution of this paper to the literature}

- This is one of the articles that examine the influence of opportunities to learn and mathematical belief on mathematical knowledge for teaching by using the structural equation modelling.

- The results indicate a significant effect of opportunities to learn on mathematical knowledge for teaching and constructivist belief.

- Opportunities to learn through teaching practice (OTL-Practicum) is the stronger factor affecting mathematical knowledge for teaching compare to opportunities to learn through a coherent teacher education program (OTL-Program).

of teachers and teaching. By introducing the PCK concept, Shulman intends to emphasize the content of lessons learned in teaching and teacher education and aims to address the differences between content and pedagogy (Depaepe, Verschaffel, \& Kelchtermans, 2013).

The mathematical knowledge for teaching (MKT) is the concept of mathematical knowledge required by a teacher to teach effectively. It includes assessing student responses, responding to questions raised by students, preparing assignments and making lesson plans (D. L. Ball, Thames, \& Phelps, 2008). According to Austin (2015), the concept of MKT developed by Ball et al. (2008), is a multi-dimensional construct consisting of subject matter knowledge (SMK) and pedagogical content knowledge (PCK).

Ernest (1989) has stated that, the differences between mathematics teachers are not only because of their knowledge, but also related to their beliefs. This is because it is possible for two different teachers to have similar knowledge, but they might be teaching the students with different approach. Teacher's beliefs have become a popular field in education-related studies because of their relationship to knowledge to teach (Thompson, 1992). According to Cross (2009) beliefs are conscious or unconscious opinions and views of the individual about himself, about the world or about his place in the world. According to Ernest (1989), there are generally three categories of beliefs associated with mathematics teachers, namely beliefs about the nature of mathematics, belief in teaching and learning, and beliefs related to principles of education. For this research, we are focusing on the belief in teaching and learning, which is also known as mathematical belief (MB) (Beswick, 2012).

In the Malaysian context, empirical studies related to the knowledge of mathematics teachers are less widely known. Among the studies conducted on the knowledge of mathematics teachers in Malaysia were by Zulhelmi Zulkpli, Mohini Mohamed, and Abdul Halim Abdullah (2017); Kwan Eu Leong, Chew Cheng Meng, and Suzieleez Syrene Abdul Rahim (2015); Yusminah Mohd Yusof, and Effandi Zakaria (2015); Harizon Suffian, and Shafia Abdul Rahman (2010); Tengku Zawawi Tengku Zainal, Ramlee Mustapha, and Abdul Razak Habib (2009) and Noraslina Hassan, and Zaleha Ismail (2008). The findings from the critical analysis that have been carried out on previous studies indicate that most previous studies are more focused on measuring the level of competence on teacher knowledge. Hence there is a need to conduct a study on MKT of mathematics teachers in Malaysia in the context of the factors that influence them.

An excellent mathematics teacher should master both domain of mathematical knowledge for teaching, either in terms of content knowledge or pedagogical content knowledge (Ball et. al., 2008). This is because the mastery of MKT is important indicator of the success of a teacher education program (Tatto, Rodriguez, \& Lu, 2015). In addition, it also affects the mathematical achievement of a pupil (Goos, 2013). However, according to Kwan Eu Leong et al. (2015) the level of MKT among pre-service teachers in Malaysia is low. The low level of MKT among pre-service teachers will contribute to the implementation of less effective teaching and learning processes (Ball et al., 2008). Hence there is a need to conduct a study to identify the factors that affect MKT among pre-service teachers.

There are several studies that have been conducted to identify the factors affecting teacher's knowledge. Among them are studies by Konig et al. (2017); Blömeke, Jenßen, Grassmann, Dunekacke, and Wedekind (2016); Qian, and Youngs (2016); Tatto et al. (2015) and Rachel A. Ayieko (2014) who studied the influence of Opportunities to Learn (OTL) on teacher knowledge. The role of OTL on the mastery of mathematical knowledge among teachers have been studied in several aspects. Among them are the influence of OTL mathematical content (OTL-Content), OTL teaching practice (OTL-Practicum), OTL a coherent teacher education program (OTL-Program), OTL mathematics pedagogy and OTL general pedagogy. The findings showed that OTL affect the teacher's knowledge directly. In addition, the OTL factor had also been found to influence the belief of a teacher. Studies by Rachel A. Ayieko (2014), and Philippou, and Christou (2002) found that there was a positive relationship between OTL and teachers' belief.

Hence, this study implements a MKT model (Ball et al., 2008), mathematical belief model (Ernest, 1989) and the concept of OTL from Carroll (1963) to examine the role of OTL (OTL-Practicum and OTL-Program) in influencing mathematical belief (MB) and MKT among pre-service teacher in Malaysia, by using structural equation modelling (SEM). 


\section{Significance of the Study}

Significance of this study is seen in terms of its contribution to theory and practice. The findings have contributed significantly to the body of knowledge by producing a comprehensive model to explain the factors affecting MKT among pre-service teachers. This model has combined both factors from the context of teachers' belief and OTL they have acquired during teacher education programs.

This study was also one of the studies on the factors affecting MKT among pre-service teachers in Institute of Teacher Education (ITE) by using SEM method. Therefore, the result of this study can be used by various stakeholders such as the Ministry of Education (MOE) Malaysia, especially the Malaysia Institute of Teacher Education (MITE) who is responsible for the training of future math teachers. The MITE can use the findings from this study as a guideline in developing a teacher education program capable of producing competent mathematics teachers. In addition, the findings of this study can also be used as references to other higher education institutions who are responsible for training potential math teachers to ensure that future teachers will master the MKT before they are placed in school.

Findings from this study can also be utilized by pre-service teachers who are studying in ITE and in any other higher education institutions to understand the factors that affect their MKT. Through that understanding, it will be able to create awareness for them to appreciate every opportunity they earned during the teacher education program.

Furthermore, the findings of this study can also be used as a reference to future researchers who study the factors affecting pre-service teachers' knowledge. The findings of this study are also expected not only relevant in the context of factors affecting pre-service teacher knowledge in mathematics, but it also includes teachers' knowledge in other disciplines. Hence this study is very significant to be carried out to contribute towards theory and practical.

\section{THEORETICAL BACKGROUND}

There are several models being used to study the role of mathematical belief and OTL in influencing CK, PCK and MKT by previous researchers. A number of studies on teacher's knowledge have been examined using the Shulman (1987) model, Fennema, and Franke (1992) model and Ball et al. (2008) model. However, the conceptual framework of the most influential teachers in the context of mathematics education is through the overlapping of some mathematical knowledge constructs for teaching (MKT) or content knowledge for the teaching of mathematics (CKTM) covering both content knowledge (CK) and pedagogical content knowledge (PCK) (Ball et al., 2008; Hill, Ball, \& Schilling, 2008; Hill, Rowan, \& Ball, 2005).

MKT means the mathematical knowledge needed to carry out the work of teaching mathematics. In short, a mathematics teacher needs to know more, and different mathematics not less (Ball et. al., 2008). MKT covers three categories that relate to teachers' CK: (1) common content knowledge (CCK), (2) specialized content knowledge (SCK), and (3) horizon content knowledge (HCK). Another set of three categories within MKT concern teachers' PCK: (4) knowledge of content and students (KCS), (5) knowledge of content and teaching (KCT), and (6) knowledge of content and curriculum (KCC) (Ball et. al., 2008).

Teachers' beliefs have become a popular field in education-related studies because of their relationship to knowledge to teach (Thompson, 1992). Although the term "belief" is very popular among educational researchers, there is no definite definition (Pajares, 1992). For example, according to (Cross, 2009) "beliefs are conscious or unconscious opinions and views of the individual about himself, about the world or about his place in the world. These opinions develop during the individual's joining in different social groups and they are considered as correct by the individual ". Philipp et al. (2007) also defines belief as "psychologically held understandings, premises, or propositions about the world that are thought to be true". Meanwhile, Richardson (1996) defines belief as "understandings, premises or propositions about the world that are felt to be true".

Based on the views of most researchers, belief is a structure that is accepted as true and can influence behaviour (Kul \& Celik, 2017). In addition, beliefs also influence the kind of knowledge teachers will use to teach in the classroom (Leinhardt \& Greeno, 1986). According to Ernest (1989), there are generally three categories of beliefs associated with mathematics teachers, namely the beliefs about nature of mathematics, beliefs about teaching and learning, and beliefs related to educational principles.

In addition to the term beliefs related to teaching and learning, there are also researchers who use the term mathematical beliefs, it carries the same meaning (Beswick, 2012). There is agreement between previous researchers that teachers' beliefs regarding mathematics teaching and learning play an important role in determining the teaching objectives of teachers and directly affect their professionalism (Cross, 2009; Philipp, 2007).

Based on the critical analysis carried out, there are two main categories of teacher mathematical beliefs, namely (1) traditional beliefs or transmission views, it means the belief that teaching mathematics is a process of knowledge 
delivery by teachers and students accepting such passive knowledge, and (2) constructivist beliefs, it means the teacher's belief that mathematics teaching is the process of helping to build student knowledge (Lim \& Chai, 2008).

The term Opportunity to Learn (OTL) was first used by Carroll (1963) to clarify the "allowed time to study", it was identified as a learning success factor during an educational program. The concept of OTL was introduced about half a century ago by the First International Mathematics Survey conducted by the International Association for the Evaluation of Educational Achievement (IEA) (Ting-Ying Wang, \& Shu-Jyh Tang, 2013). The concept of OTL is usually used in evaluating the effectiveness of a teacher education program. The OTL serves as an indicator of the variation of the curriculum and the diversity of lessons learned by a pre-service teacher (Tatto et al., 2008).

\section{RESEARCH MODEL}

A study conducted by Swars, Hart, Smith, Smith, and Tolar (2007) found that mathematical beliefs factor has influenced teacher knowledge. The study was conducted among 103 elementary pre-service teachers. Additionally, recent studies conducted by Ren, and Smith (2017) also found that teachers' belief factor influenced the mastery of mathematical knowledge for teaching among teachers. The findings from the study on 396 early teachers found that there was a significant relationship between traditional beliefs and mathematical knowledge for teaching.

Furthermore, the research conducted by Meschede, Fiebranz, Möller, and Steffensky (2017) on teachers teaching elementary science has proven that the beliefs in teaching and learning had influenced the teacher's knowledge. The findings from their research had found that constructivist belief factor influenced the teachers' knowledge $(\beta=0.52, p<0.001)$. While the traditional beliefs factor also had a significant relationship with the teacher's knowledge $(\beta=-0.37, p<0.001)$. Therefore, this study will also examine the influence of mathematical beliefs on the MKT among pre-service teachers in ITE.

H1: Constructivist belief has a direct and significant influence on mathematical knowledge for teaching

H2: Traditional belief has a direct and significant influence on mathematical knowledge for teaching

Previous studies have shown that OTL variables influence the teacher's knowledge and teacher's belief. Among them are studies by Rachel A. Ayieko (2014) on the teachers from three country found that the opportunity to learn mathematics pedagogy has influence their belief and knowledge. Besides that, the study conducted by Konig et al. (2017) on prospective high school English teachers found that OTL content and OTL teaching practices have influenced their pedagogical content knowledge. Regression analysis showed that OTL was able to predict the positive score of the PCK test teacher $(\beta=0.28(p<0.01)$ for OTL content, and $(\beta=0.29(p<0.01)$ for OTL teaching practice (practicum). In addition, the study by Akkoç, and Yesildere (2010) also found that OTL teaching practice (practicum) influence teachers' PCK significantly.

The study by Kleickmann et al. (2013) and Tatto et al. (2012) on pre-service teachers also found the opportunity to follow the coherent teacher education program (OTL-Program) also influenced the mastery of CK and PCK of the teacher. This clearly shows that OTL is an important factor affecting the mastery of knowledge and academic achievement of future teachers. In addition, recent studies conducted by Livy and Downton (2018) also found that the OTL-Practicum factor has influenced the mastery of mathematical knowledge for teaching among pre-service teachers. The findings from the case study conducted among 20 second-year pre-service teacher found that the course experiences provided an opportunity to extend pre-service teachers' knowledge. Hence, this study will also examine the influence of OTL on the MKT among pre-service teachers at ITE.

H3: Opportunity to learn teaching practice (OTL-Practicum) has a direct and significant influence on mathematical knowledge for teaching.

H4: Opportunity to follow the coherent teacher education program (OTL-Program) has a direct and significant influence on mathematical knowledge for teaching.

H5: Opportunity to learn teaching practice (OTL-Practicum) has a direct and significant influence on constructivist belief.

H6: Opportunity to follow the coherent teacher education program (OTL-Program) has a direct and significant influence on constructivist belief. belief.

H7: Opportunity to learn teaching practice (OTL-Practicum) has a direct and significant influence on traditional

H8: Opportunity to follow the coherent teacher education program (OTL-Program) has a direct and significant influence on traditional belief. 


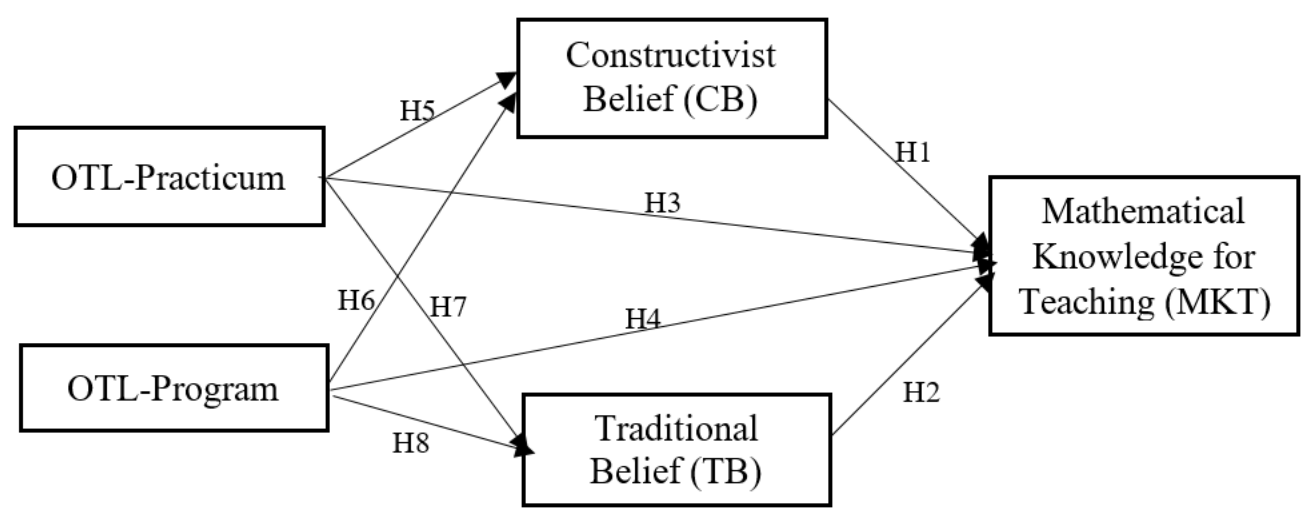

Figure 1. The research model

\section{METHOD}

\section{Data Collection}

Data was collected from 105 preservice teachers using a structured questionnaire and paper and pencil test. Both measures were adapted from previous research done by other researchers. We have used the clustered random sampling method to collect the data. This method was chosen because this study was conducted on populations involving large areas. The population of this study involves pre-service teachers who are currently pursuing Mathematics Education Program from semester 6 to 8 nationwide. Besides that, the clustered random sampling was used because the population of this study was widely scattered, and it is impractical to sample and select a representative sample of all the elements. Hence the sample of the study has been divided into several groups based on ITEs involved in the training of pre-service teacher in mathematics education. It was found that 13 out of 27 ITEs nationwide were involved in the training of pre-service teachers in mathematics education. Thus, the sample was divided into 13 groups, and then the sample selection from the cluster was randomly made to ensure that each sample had the same opportunity to be selected as a sample of the study (Acharya, Prakash, Saxena, \& Nigam, 2013). The justification for the selection of all pre-service teachers of mathematics education in semesters 6 to 8 is that they have followed most courses offered and have undergone practicum training Phase 1. In addition, their selection as the study population is due to the issues studied have a direct connection with them.

\section{Measures}

The measure for OTL-Practicum and OTL-Program was adapted from Tatto, Senk, and Rowley (2008). These items are part of the items used in the TEDS-M 2008 study by the International Association for the Evaluation of Educational Achievement (IEA). It contains 8 items that measure OTL-Practicum and 6 items that measure OTLProgram. Permission to adopt the instrument has been applied and granted approval. They reported comparative fit index (CFI) for OTL-Practicum were 0.953, while for OTL-Program were 0.99 (Tatto, 2013). This illustrates that items are suitable for measuring the constructs. This is because the CFI value for the constructs exceeds 0.95 (Hu, \& Bentler, 1999). It consisted of 14 Likert type items (OTL-Practicum $=8$ items and OTL-Program $=6$ items).

Mathematical belief measures were adapted from Effandi Zakaria et al. (2009). The instrument has been developed to measure mathematical beliefs among teachers in constructivist and traditional approaches. It contains 12 items, which is 8 items that measure constructivist beliefs and 4 items that measure traditional beliefs. Findings from Confirmatory Factor Analysis conducted by Mazlini Adnan, Mohd Faizal Nizam Lee Abdullah, and Che Nidzam Che Ahmad (2014) on the instrument indicates that the items are suitable for measuring mathematical beliefs. They reported the comparative fit index (CFI) value for the mathematical belief construct was 0.983.

Whereas MKT test was adapted from Hill, Schilling, and Ball (2004). It consisted of 32 multiple choice items. They reported the level of reliability of items that measure CK of primary school mathematics teacher for number and operation topics $\alpha=0.784$, while for PCK was $\alpha=0.888$ (Hill et al., 2004). This illustrates the level of reliability of both constructs is good. The validity of the items used in the MKT test has been determined by items analysis. Item analysis has been carried out to distinguish good items with poor items. Item analysis is intended to produce a high-quality test (Considine, Botti, \& Thomas, 2005). Item analysis will be able to provide information regarding the response to each item whether they are able to answer or not that item. It also provides information on how each item works, whether the item is easy or difficult. In addition, an item analysis can discriminate between higher 
Table 1. Descriptive statistics results of participants

\begin{tabular}{lcc}
\hline & Frequency & Percent \\
\hline Gender & & 34.3 \\
Male & 36 & 65.7 \\
Female & 69 & 20 \\
\hline Ethnicity & & 46.7 \\
Malay & 21 & 28.6 \\
Chinese & 49 & 4.8 \\
Indian & 30 & \\
Others & 5 & 25.7 \\
\hline Cumulative Grade Point Average (CGPA) & & 71.4 \\
$3.75-4.00$ & 27 & 2.9 \\
$3.00-3.74$ & 75 & 0 \\
$2.00-2.99$ & 3 & \\
$0-1.99$ & 0 & \\
\hline
\end{tabular}

performance groups and lower performance groups (Si-Mui Sim, \& Raja Isaiah Rasiah, 2006). ANATES 4.0.9 (Karno, \& Wibisono, 2004) software was used to analyse the MKT test items.

\section{Sample}

The study sample was consisted of 105 pre-service teachers from ITE (65.7\% were female). Majority of the preservice teachers involved in this study are Chinese (46.7\%), whereas Malays about $20 \%$, Indian $28.6 \%$ and others $4.8 \%$. The CGPA obtained was quite high, which was almost $97 \%$ of them got the CGPA above 3.00. This showed that their academic achievements were good.

\section{DATA ANALYSIS}

For this study, the researcher has used the SmartPLS 3.0 software to analyse the data. SmartPLS 3.0 was used to analyse the data for this study because it was suitable to answer the research question. According to Hair, Ringle, and Sarstedt (2011) if the research goal is exploratory so we should use PLS-SEM. When analysing the data we have followed the analysis procedure as suggested by Hair, Hult, Ringle, and Sarstedt (2017). Firstly, we analyse the measurement model and then followed by analysing the structural model. This is to make sure the measures used in the study are reliable and valid to answer the research questions.

\section{Measurement Model}

When using multiple measures for an individual construct, the researcher should take into consideration the extent to which the measures demonstrate convergent validity (Hulland, 2002). Hair et al. (2017) has stated that a composite reliability (CR) of 0.70 or above and an average variance extracted (AVE) of more than 0.50 are considered acceptable. The result of Confirmatory Factor Analysis (CFA) stated in Table 2 shows that all the composite reliability values are above 0.70 and the AVE is all above 0.50 . Therefore, based on the CFA result obtained, we can conclude that convergent validity for this measurement model has been fulfilled. 
EURASIA J Math Sci and Tech Ed

Table 2. Result of CFA for measurement model

\begin{tabular}{|c|c|c|c|c|c|}
\hline \multirow{2}{*}{ Construct } & \multirow{2}{*}{ Item } & \multirow{2}{*}{$\begin{array}{l}\text { Internal Reliability } \\
\text { (Cronbach Alpha) }\end{array}$} & \multicolumn{3}{|c|}{ Convergent Validity } \\
\hline & & & $\begin{array}{c}\text { Factor } \\
\text { Loading }\end{array}$ & $\begin{array}{l}\text { Composite } \\
\text { Reliability }^{a}\end{array}$ & $\begin{array}{c}\text { Average Variance } \\
\text { Extracted }^{b}\end{array}$ \\
\hline \multirow{6}{*}{ OTL-Practicum } & OTL_Prac1 & \multirow{6}{*}{0.840} & 0.687 & \multirow{6}{*}{0.880} & \multirow{6}{*}{0.552} \\
\hline & OTL_Prac2 & & 0.798 & & \\
\hline & OTL_Prac3 & & 0.637 & & \\
\hline & OTL_Prac4 & & 0.709 & & \\
\hline & OTL_Prac5 & & 0.796 & & \\
\hline & OTL_Prac6 & & 0.814 & & \\
\hline \multirow{5}{*}{ OTL-Program } & OTL_Prog1 & \multirow{5}{*}{0.879} & 0.761 & \multirow{5}{*}{0.911} & \multirow{5}{*}{0.673} \\
\hline & OTL_Prog2 & & 0.799 & & \\
\hline & OTL_Prog3 & & 0.877 & & \\
\hline & OTL_Prog4 & & 0.798 & & \\
\hline & OTL_Prog5 & & 0.862 & & \\
\hline \multirow{5}{*}{ Constructivist Belief } & CB1 & \multirow{5}{*}{0.777} & 0.714 & \multirow{5}{*}{0.846} & \multirow{5}{*}{0.523} \\
\hline & CB2 & & 0.740 & & \\
\hline & CB3 & & 0.695 & & \\
\hline & CB4 & & 0.732 & & \\
\hline & CB5 & & 0.733 & & \\
\hline \multirow{3}{*}{ Traditional Belief } & TB1 & \multirow{3}{*}{0.704} & 0.694 & \multirow{3}{*}{0.805} & \multirow{3}{*}{0.584} \\
\hline & TB2 & & 0.916 & & \\
\hline & TB3 & & 0.658 & & \\
\hline Mathematical Knowledge for Teaching & & $\mathrm{N} / \mathrm{A}^{a}$ & & $\mathrm{~N} / \mathrm{A}^{a}$ & $\mathrm{~N} / \mathrm{A}^{a}$ \\
\hline
\end{tabular}

Note:

a Single item measures

Table 3. Discriminant validity

\begin{tabular}{llllll}
\hline Constructs & $\mathbf{( 1 )}$ & $\mathbf{( 2 )}$ & (3) & (4) & (5) \\
\hline (1) Constructivist Belief & $\mathbf{0 . 7 2 3}$ & & & & \\
\hline (2) MKT & 0.293 & N/A $^{a}$ & & & \\
\hline (3) OTL-Practicum & 0.304 & 0.651 & $\mathbf{0 . 7 4 3}$ & & \\
\hline (4) OTL-Program & 0.325 & 0.567 & 0.398 & $\mathbf{0 . 8 2 1}$ & \\
\hline (5) Traditional Belief & -0.502 & -0.072 & -0.007 & -0.241 & $\mathbf{0 . 7 6 4}$ \\
\hline
\end{tabular}

Note:

a Single item measures

Besides convergent validity, the researcher also need to take into consideration about discriminant validity in order to make sure the items used to measure a certain construct are different with other construct in the model. According to Fornell and Larcker (1981) discriminant validity can be established by calculating the square root of the AVE. Besides that, Hair et.al (2017) also stated that discriminant validity also can be establish by assessing the cross loading and heterotrait-monotrait ratio of correlations (HTMT) value. For this study we are only used square root of the AVE to assess the discriminant validity.

\section{Structural Model and Hypothesis Testing}

Structural model analysis are not only tests hypotheses but also estimates path coefficients of constructs by examining the relationship between the dependent and independent variables and the amount of variance which can be explained by the independent variables $\left(\mathrm{R}^{2}\right)$ as well as by the overall model. Table 4 and Figure 2 shows that $\mathrm{H} 3, \mathrm{H} 4, \mathrm{H} 5, \mathrm{H} 6$, and $\mathrm{H} 8$ were significant. 


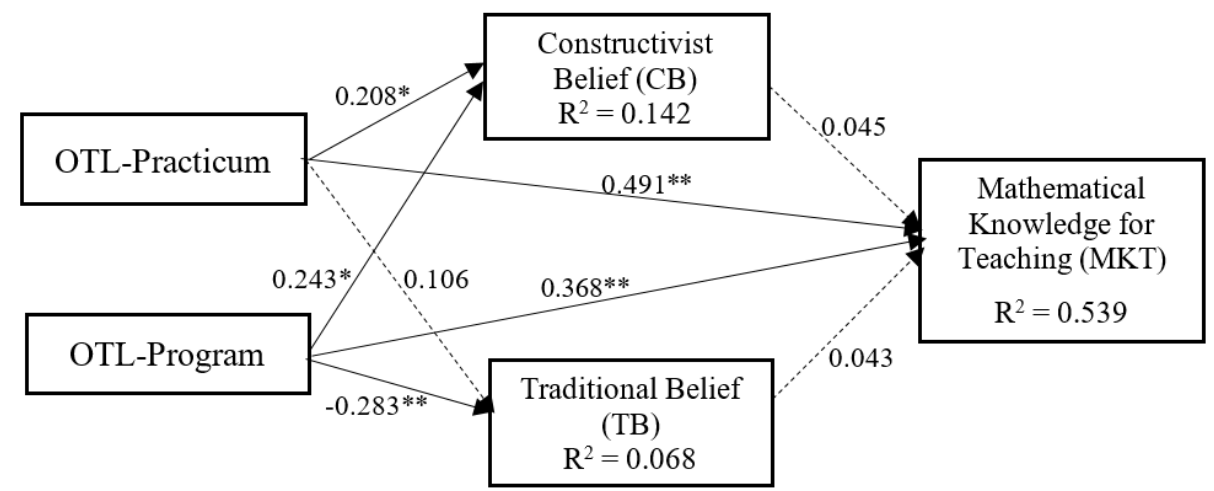

Figure 2. The research model

Table 4. Summary of hypothesis tests

\begin{tabular}{lccc}
\hline Hypothesis & $\begin{array}{c}\text { Standardized path } \\
\text { coefficients }(\boldsymbol{\beta})\end{array}$ & t-value & Supported \\
\hline H1. CB $\rightarrow$ MKT & 0.045 & 0.647 & No \\
\hline H2. TB $\rightarrow$ MKT & 0.043 & 0.549 & No \\
\hline H3. OTL-Practicum $\rightarrow$ MKT & $0.491^{\star \star}$ & 8.835 & Yes \\
\hline H4. OTL-Program $\rightarrow$ MKT & $0.368^{\star \star}$ & 6.381 & Yes \\
\hline H5. OTL-Practicum $\rightarrow$ CB & $0.208^{*}$ & 2.164 & Yes \\
\hline H6. OTL-Program $\rightarrow$ CB & $0.243^{*}$ & 2.557 & Yes \\
\hline H7. OTL-Practicum $\rightarrow$ TB & 0.106 & 0.734 & No \\
\hline H8. OTL-Program $\rightarrow$ TB & $-0.283^{\star \star}$ & 2.754 & Yes \\
\hline
\end{tabular}

Note: ${ }^{*} \mathrm{p}$-value $<0.05 ;{ }^{* \star} \mathrm{p}$-value $<0.001$

Table 5. Squared multiple correlations $\left(R^{2}\right)$ of the proposed research model

\begin{tabular}{ll}
\hline Constructs & $\mathbf{R}^{\mathbf{2}}$ \\
\hline Mathematical Knowledge for Teaching & 0.539 \\
\hline Constructivist Belief & 0.142 \\
\hline Traditional Belief & 0.068 \\
\hline
\end{tabular}

The results demonstrated that, (1) OTL-Practicum had a positive effect on MKT $(\beta=0.491, p<0.001)$; (2) OTLProgram had a positive effect on MKT $(\beta=0.368, p<0.001)$; (3) OTL-Practicum had a positive effect on constructivist belief $(\beta=0.208, p<0.05)$; (4) OTL-Program had a positive effect on constructivist belief $(\beta=0.243, p<0.05)$ and $(5)$ OTLProgram had a negative effect on traditional belief $(\beta=-0.283, p<0.001)$. The results of the structural model analysis are illustrated in Figure 2. Overall, the model explained $53.9 \%$ of the variance in mathematical knowledge for teaching (Table 5).

\section{RESULTS AND DISCUSSION}

The purpose of this study was to test a model of factors affecting mathematical knowledge for teaching among preservice teachers in Malaysia. Due to that, this study examined the relationship between mathematical belief (in term of constructivist belief and traditional belief) and MKT, and the impact of opportunities to learn (OTL) on MKT and mathematical belief.

The results of the multiple regression analysis for this study are parallel with those found in a similar study by Rachel A. Ayieko (2014) where both dimensions of opportunity to learn were positively related to mathematical belief. Besides that, the findings are also consistent with Konig et al. (2017), and Akkoç, and Yesildere (2010) findings which stated that there is a significant relationship between preservice teachers' opportunity to learn through teaching practice (OTL-Practicum) and their pedagogical content knowledge. Furthermore, earlier findings by Toh Tin Lam, Berinderjeet Kaur, and Koay Phong Lee (2009) have established that OTL-Practicum affected Singapore preservice secondary mathematics teachers' content knowledge. In addition, a similar study by Tatto et al. (2015) and Kleickmann et al. (2013) also found that opportunity to follow the coherent teacher education program (OTL-Program) influenced the mastery of CK and PCK of the teacher. Surprisingly the result of this study was not consistent with finding from previous study done by Meschede et al. (2017). This is because it was found that MKT are not affected by both of the mathematical belief dimension (constructivist belief and traditional belief). 
The role of MITE as an institution responsible for producing competent mathematics teachers is that it is desirable that MOE provide enough allocation to ensure that the widest possible learning opportunities can be enjoyed by pre-service teachers. Apart from providing opportunities to learn through a coherent teacher education programs, a pre-service teacher should also be given the opportunity to learn the pedagogical knowledge more effectively. This is because according to Blömeke et al. (2016) the OTL general pedagogical and mathematical pedagogy can influence the knowledge level of pre-service teachers. The delivery of pedagogical knowledge to preservice teachers is directly related to the curriculum structure and quality of a teacher educators. Therefore, in order to ensure the delivery of more relevant pedagogical knowledge, it is recommended that the MITE regularly update the mathematics education curriculum while continuing to improve the mathematics teacher educator's competency in the delivery of pedagogical-related knowledge.

The model tested in this study shows that OTL-Practicum and OTL-Program can account for $14.2 \%$ of the variance in constructivist belief while about $53.9 \%$ of the variance in mathematical knowledge for teaching. These results suggest that the tested model are able to predict the mathematical belief and teachers' knowledge.

The contributions of this study towards Institute of Teachers Education (ITE) and implementers are there was a need for both of them to provide necessary opportunities to learn to the pre-service teachers in order to ensure they can increase their MKT. If preservice teachers' MKT is low because of lack of OTL, it will affect the teacher education program implementation. Enough and adequate opportunities to learn provided by the ITE seem to bring a greater teacher education program to the pre-service teachers.

\section{LIMITATIONS AND FURTHER RESEARCH}

This study empirically tested the effect of opportunities to learn and mathematical belief on mathematical knowledge for teaching. Although the finding of this study was really useful, there are certain limitations regarding this study. Therefore our findings need to be interpreted appropriately. The first consideration was that the sample size used in this study need to be take into account when generalizing the results of the study. This is because this study only involved a small sample size $(\mathrm{N}=105)$. Besides that, this study are only focused on testing the effect of opportunities to learn, mathematical belief and mathematical knowledge for teaching. There might be any other related variables that can affect MKT.

In the future, this study can be expand by (1) integrating the influence of mathematics teaching efficacy belief (MTEB) on the MKT among pre-service teachers, (2) including the effect of other OTL factors, such as OTL mathematics content, OTL general pedagogy and OTL mathematics pedagogy on the MKT among pre-service teachers and (3) expanding the model by adding other relevant variables found from latest literature. Besides that, future studies also can make a comparison of mathematical knowledge for teaching between pre-service and inservice teachers considering the fact that in-service teachers should have a better mathematical knowledge for teaching due to their teaching experiences.

\section{CONCLUSION}

According to the findings, we found that opportunity to learn teaching practice (OTL-Practicum) and opportunity to follow a coherent teacher education program (OTL-Program) are significant factors influencing mathematical knowledge for teaching among pre-service teachers in Malaysia. The findings of this study may enable the teacher education program provider to take into consideration on these variables that will influence mathematical knowledge for teaching. In addition, this study may provide an empirical justification for the ITE to develop a strategic plan that can improve the teacher education program by focusing on the pre-service teachers' opportunities to learn. In the future, there was a need to conduct further research to enhance this study. We believe this study are able to give a preparatory knowledge and comprehension on the role of opportunities to learn and mathematical belief in maximizing the mastery of mathematical knowledge for teaching.

\section{REFERENCES}

Acharya, A. S., Prakash, A., Saxena, P., \& Nigam, A. (2013). Sampling : Why and How of it? Indian Journal of Medical Specialities, 4(2), 330-333. http:/ / doi.org/10.7713/ijms.2013.0032

Adnan M., Abdullah M. F. N. L., \& Che Ahmad C. N. (2014). Aplikasi Model Persamaan Berstruktur dalam Menilai Kepercayaan dan Pengetahuan Konseptual Guru Matematik Sekolah Rendah. Jurnal Pendidikan Matematik, 2(1), 32-50.

Akkoç, H., \& Yesildere, S. (2010). Investigating development of pre-service elementary mathematics teachers' pedagogical content knowledge through a school practicum course. Procedia - Social and Behavioral Sciences, 2(2), 1410-1415. http:/ / doi.org/10.1016/j.sbspro.2010.03.210 
Austin, J. (2015). Prospective Teachers' Personal Mathematics Teacher Efficacy Beliefs and Mathematical Knowledge for Teaching. Mathematics Education, 10(1), 17-36. http:/ / doi.org/10.12973/mathedu.2015.102a

Ayieko R. A. (2014). The Influence of Opportunity to Learn to Teach Mathematics on Pre-service Teachers' Knowledge and Belief: A Comparative Study. Michigan State University.

Ball, D. L. (2000). Bridging Practices: Intertwining Content and Pedagogy in Teaching and Learning to Teach. Journal of Teacher Education, 51(3), 241-247. http:/ / doi.org/10.1177/0022487100051003013

Ball, D. L., Thames, M. H., \& Phelps, G. (2008). Content Knowledge for Teaching: What Makes It Special? Journal of Teacher Education, 59(5), 389-407. http:/ / doi.org/10.1177/0022487108324554

Beswick, K. (2012). Teachers' beliefs about school mathematics and mathematicians' mathematics and their relationship to practice. Educational Studies in Mathematics, 79(1), 127-147. http:/ /doi.org/10.1007/s10649011-9333-2

Blömeke, S., Jenßen, L., Grassmann, M., Dunekacke, S., \& Wedekind, H. (2016). Process Mediates Structure: The Relation Between Preschool Teacher Education and Preschool Teachers' Knowledge. Journal of Educational Psychology, 109(3), 338-354. http:/ / doi.org/10.1037/edu0000147

Bloom, B. S., Englehard, M. D., Furst, E. J., Hill, W. H., \& Krathwohl, D. R. (1956). Taxonomy of educational objectives: The classification of educational goals: Handbook I, cognitive domain. New York (Vol. 16). http:/ / doi.org/10.1300/J104v03n01_03

Carroll, J. (1963). A model of school learning. Teachers College Record, 64, 723-733.

Considine, J., Botti, M., \& Thomas, S. (2005). Design, format, validity and reliability of multiple choice questions for use in nursing research and education. Collegian, 12(1), 19-24. http:/ / doi.org/10.1016/S1322-7696(08)604783

Cross, D. I. (2009). Alignment, cohesion, and change: Examining mathematics teachers' belief structures and their influence on instructional practices. Journal of Mathematics Teacher Education, 12(5), 325-346. http:/ / doi.org/10.1007/s10857-009-9120-5

Depaepe, F., Verschaffel, L., \& Kelchtermans, G. (2013). Pedagogical content knowledge: A systematic review of the way in which the concept has pervaded mathematics educational research. Teaching and Teacher Education, 34, 12-25. http:/ / doi.org/10.1016/j.tate.2013.03.001

Ernest, P. (1989). The Knowledge, Beliefs and Attitudes of the Mathematics Teacher: a model. Journal of Education for Teaching: International Research and Pedagogy, 15(1), 13-33. http:/ / doi.org/10.1080/0260747890150102

Fennema, E., \& Franke, M. L. (1992). Teachers' knowledge and its impact. In Handbook of research on mathematics teaching and learning: A project of the National Council of Teachers of Mathematics (pp. 147-164).

Fitzallen, N. (2015). STEM education: What does mathematics have to offer? 38th Annual Conference of the Mathematics Education Research Group of Australasia, (June), 237-244.

Fornell, C., \& Larcker, D. F. (1981). Evaluating Structural Equation Models with Unobservable Variables and Measurement Error. Journal of Marketing Research, 18(1), 39. http:/ / doi.org/10.2307/3151312

Goos, M. (2013). Knowledge for teaching secondary school mathematics: what counts? International Journal of Mathematical Education in Science and Technology, 44(7), 972-983. http:/ / doi.org/10.1080/0020739X.2013.826387

Hair, J. F. J., Hult, G. T. M., Ringle, C. M., \& Sarstedt, M. (2017). A Primer on Partial Least Squares Structural Equation Modeling (PLS-SEM). SAGE Publications Ltd.

Hair, J. F., Ringle, C. M., \& Sarstedt, M. (2011). PLS-SEM: Indeed a Silver Bullet. Journal of Marketing Theory and Practice, 19(2), 139-152. http:/ / doi.org/10.2753/MTP1069-6679190202

Hassan N., \& Ismail Z. (2008). Pengetahuan Pedagogi Kandungan Guru Pelatih Matematik Sekolah Menengah. Seminar Kebangsaan Pendidikan Sains Dan Matematik, 1-14.

Hiebert, J., \& Carpenter, T. P. (1992). Learning and teaching with understanding. In Handbook of research on mathematics teaching and learning: A project of the National Council of Teachers of Mathematics (pp. 65-97).

Hill, H. C., Ball, D. L., \& Schilling, S. G. (2008). Unpacking Pedagogical Content Knowledge: Conceptualizing and measuring teachers' topic-specific knowledge of students. Journal for Research in Mathematics Education, 39(4), 372-400. http:/ / doi.org/Article

Hill, H. C., Rowan, B., \& Ball, D. L. (2005). Effects of Teachers' Mathematical Knowledge for Teaching on Student Achievement. American Educational Research Journal, 42(2), 371-406.

Hill, H. C., Schilling, S. G., \& Ball, D. L. (2004). Developing Measures of Teachers' Mathematics Knowledge for Teaching. The Elementary School Journal, 105(1), 11-30. 
Holmes, V. (2012). Depth of Teachers' Knowledge : Frameworks for Teachers ‘ Knowledge of Mathematics. Journal of STEM Education, 13(1), 55-71.

Hu, L. T., \& Bentler, P. M. (1999). Cutoff criteria for fit indexes in covariance structure analysis: Conventional criteria versus new alternatives. Structural Equation Modeling, 6(1), 1-55. http:/ / doi.org/10.1080/10705519909540118

Hulland, J. (2002). Use of partial least squares (PLS) in strategic management research: A review of four recent studies. Strategic Management Journal, 8(2), 195-204. http:/ / doi.org/10.1002/smj.431

Kleickmann, T., Richter, D., Kunter, M., Elsner, J., Besser, M., Krauss, S., \& Baumert, J. (2013). Teachers' Content Knowledge and Pedagogical Content Knowledge : The Role of Structural Differences in Teacher Education. Journal of Teacher Education, 64(1), 90-106. http:/ / doi.org/10.1177/0022487112460398

Konig, J., Tachtsoglou, S., Lammerding, S., Straub, S., Nold, G., \& Rohde, A. (2017). The Role of Opportunities to Learn in Teacher Preparation for EFL Teachers' Pedagogical Content Knowledge. The Modern Language Journal, 101(1), 1-19. http:/ / doi.org/10.1111/modl.12383

Kul, U., \& Celik, S. (2017). Exploration of Pre- service Teachers ' Beliefs in relation to Mathematics Teaching Activities in Classroom-based Setting. International Journal of Research in Education and Science (IJRES), 3(1), 245-257.

Leinhardt, G., \& Greeno, J. G. (1986). The cognitive skill of teaching. Journal of Educational Psychology, 78(2), 75-95. http:/ / doi.org/10.1037/0022-0663.78.2.75

Leong K. E., Chew C. M, \& Abdul Rahim S. S. (2015). Understanding Malaysian pre-service teachers mathematical content knowledge and pedagogical content knowledge. Eurasia Journal of Mathematics, Science and Technology Education, 11(2), 363-370. http:/ / doi.org/10.12973/eurasia.2015.1346a

Lim, C. P., \& Chai, C. S. (2008). Teachers' pedagogical beliefs and their planning and conduct of computer-mediated classroom lessons. British Journal of Educational Technology, 39(5), 807-828. http://doi.org/10.1111/j.14678535.2007.00774.x

Livy, S., \& Downton, A. (2018). Exploring experiences for assisting primary pre-service teachers to extend their knowledge of student strategies and reasoning. Journal of Mathematical Behavior, (November 2016), 1-11. http:/ / doi.org/10.1016/j.jmathb.2017.11.004

Meschede, N., Fiebranz, A., Möller, K., \& Steffensky, M. (2017). Teachers' professional vision, pedagogical content knowledge and beliefs: On its relation and differences between pre-service and in-service teachers. Teaching and Teacher Education, 66, 158-170. http:/ / doi.org/10.1016/j.tate.2017.04.010

Mohd Yusof Y., \& Zakaria E. (2015). The Integration of Teacher's Pedagogical Content Knowledge Components in Teaching Linear Equation. International Education Studies, 8(11), 26-33. http:/ / doi.org/10.5539/ies.v8n11p26

NCTM. (2000). Principles and Standards for School Mathematics. United States of America: The National Council of Teachers of Mathematics, Inc.

Pajares, M. F. (1992). Teachers' Beliefs and Educational Research: Cleaning Up a Messy Construct. Review of Educational Research, 62(3), 307-332. http:/ / doi.org/10.3102/00346543062003307

Philipp, R. A., Ambrose, R., Lamb, L. L. C., Sowder, J. T., Schappelle, B. P., Sowder, L., ... Nickerson, S. (2007). Effects of Early Field Experiences on the Mathematical Content Knowledge and Beliefs of Prospective Elementary School Teachers: An Experimental Study. Journal for Research in Mathematics Education, 38(5), 438-476. http:// doi.org/10.2307/30034961

Philippou, G., \& Christou, C. (2002). A Study of the Mathematics Teaching Efficacy Belief of a Primary Teachers. In Beliefs: A Hidden Variable in Mathematics Education? (pp. 211-231). Netherlands: Kluwer Academic Publishers.

Porter, A. C. (2002). Measuring the content of instruction: Uses in research and practice. Educational Researcher, 31(7), 3-14. http:/ / doi.org/10.3102/0013189X031007003

Qian, H., \& Youngs, P. (2016). The effect of teacher education programs on future elementary mathematics teachers' knowledge: a five-country analysis using TEDS-M data. Journal of Mathematics Teacher Education, 19(4), 371396. http:/ / doi.org/10.1007/s10857-014-9297-0

Ren, L., \& Smith, W. M. (2017). Teacher characteristics and contextual factors: links to early primary teachers' mathematical beliefs and attitudes. Journal of Mathematics Teacher Education, pp. 1-30. http:/ / doi.org/10.1007/s10857-017-9365-3

Richardson, V. (1996). The role of attitudes and beliefs in learning to teach.

Shulman, L. S. (1986). Those who understand: knowledge growth in teaching. Educational Researcher, 15(2), 4-14.

Shulman, L. S. (1987). Knowledge and Teaching: Foundations of the New Reform. Harvard Educational Review, 57(1), $1-21$. 
Si-Mui Sim, \& Raja Isaiah Rasiah. (2006). Relationship between item difficulty and discrimination indices in true/false-type multiple choice questions of a para-clinical multidisciplinary paper. Annals of the Academy of Medicine Singapore, 35(2), 67-71.

Skemp, R. R. (1978). Relational Understanding and Instrumental Understanding. The Arithmetic Teacher, 26(3), 915. http://doi.org/10.1017/CBO9781107415324.004

Suffian H., \& Abdul Rahman S. (2010). Teachers' choice and use of examples in the teaching and learning of mathematics in primary school and their relations to teacher's pedagogical content knowledge (PCK). Procedia - Social and Behavioral Sciences, 8(5), 312-316. http:/ / doi.org/10.1016/j.sbspro.2010.12.043

Swars, S., Hart, L. C., Smith, S. Z., Smith, M. E., \& Tolar, T. (2007). A Longitudinal Study of Elementary Pre-service Teachers' Mathematics Beliefs and Content Knowledge. School Science and Mathematics, 107(8), 325-335. http://doi.org/10.1111/j.1949-8594.2007.tb17797.x

Tatto, M. T. (2013). The Teacher Education and Development Study in Mathematics (TEDS-M): Policy, Practice, and Readiness to Teach Primary and Secondary Mathematics in 17 Countries. Technical Report. http://doi.org/10.1038/nn.2116

Tatto, M. T., Peck, R., Schwille, J., Bankov, K., Senk, S. L., Rodriguez, M., ... Rowley, G. (2012). Policy, Practice, and Readiness to Teach Primary and Secondary Mathematics in 17 Countries: Findings from the IEA Teacher Education and Development Study in Mathematics (TEDS-M-M). International Association for the Evaluation of Educational Achievement. Retrieved from http:/ / eric.ed.gov/?id=ED542380

Tatto, M. T., Rodriguez, M., \& Lu, Y. (2015). The Influence of Teacher Education on Mathematics Teaching Knowledge: Local Implementation of Global Ideals. Promoting and Sustaining a Quality Teacher Workforce, 27(1), 279-331. http:/ / doi.org/10.1108/IJBM-07-2013-0069

Tatto, M. T., Senk, S. L., \& Rowley, G. (2008). Teacher Education and Development Study in Mathematics (TEDS-M).

Tengku Zainal T. Z., Mustapha R., \& Habib A. R. (2009). Pengetahuan Pedagogi Isi Kandungan Guru Matematik bagi Tajuk Pecahan: Kajian Kes di Sekolah Rendah. Jurnal Pendidikan Malaysia, 34(1), 131-153.

Thompson, A. G. (1992). Teachers' beliefs and conceptions: A synthesis of the research. Handbook of Research on Mathematics Teaching and Learning, 127-146.

Ting-Ying Wang, \& Shu-Jyh Tang. (2013). Profiles of Opportunities To Learn for Teds-M Future Secondary Mathematics Teachers. International Journal of Science and Mathematics Education, 11(4), 847-877. http:/ / doi.org/10.1007/s10763-013-9421-0

Toh T. L., Berinderjeet K., \& Koay P. L. (2009). Singapore Pre-service Secondary Mathematics Teachers' Content Knowledge : Findings from an International Comparative Study. The Mathematics Educator, 1-22.

Wasserman, N. H. (2018). Knowledge of nonlocal mathematics for teaching. Journal of Mathematical Behavior, 49(November 2017), 116-128. http:/ / doi.org/10.1016/j.jmathb.2017.11.003

Zakaria E., Halim L., Abdullah K., Mohd Nordin N., Mohamad N. S., \& Daud M. Y. (2009). Pembangunan instrumen kepercayaan guru-guru pra-perkhidmatan terhadap matematik, pengajaran matematik dan pembelajaran matematik. Laporan Penyelidikan. Fakulti Pendidikan UKM.

Zulkpli Z., Mohamed M., \& Abdullah A. H. (2017). Assessing Mathematics Teachers' Knowledge in Teaching Thinking Skills. Sains Humanika, 9(1-4), 83-87. http:/ / doi.org/10.11113/sh.v9n1-4.1129 


\section{APPENDICES}

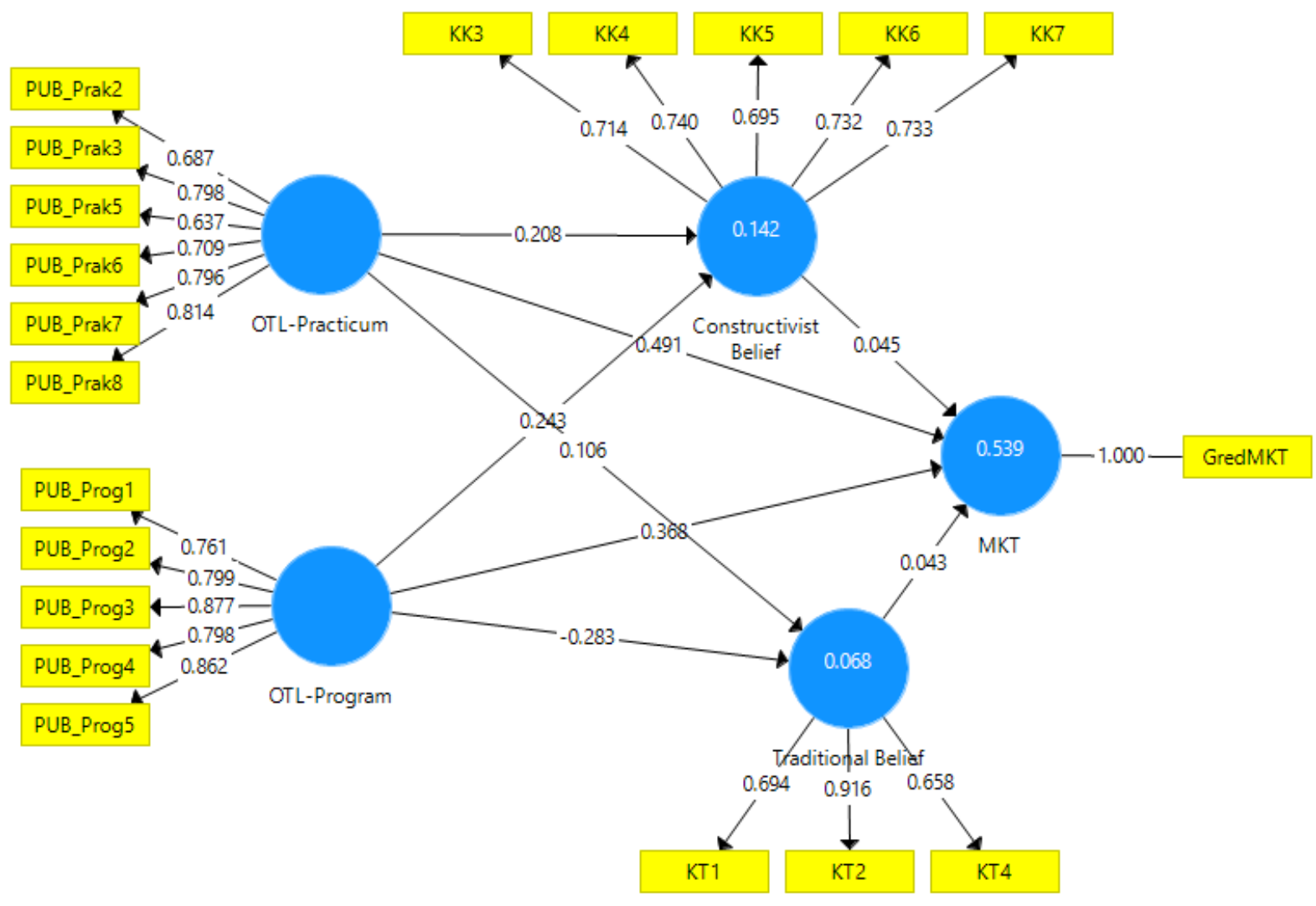

http://www.ejmste.com 